\title{
The Kingdom of God in the Church and the Experience of Human History
}

\author{
Francis Appiah-Kubi 1 \& Isaac Osei Karikari ${ }^{2}$ \\ ${ }^{1}$ Department of Religious Studies, Kwame Nkrumah University of Science and Technology, Kumasi-Ghana. \\ 2 Trinity Theological Seminary, Legon Accra - Ghana.
}

\begin{abstract}
Understanding the idea of the reign of God in the affairs of humans must not only be envisaged or experienced by the ecclesiastical setting or arena. The hope in the existence of God's kingdom transcends the spiritual emphasis to the socio-cultural and politico-economic realms. This article looks at the penetrating effects of the Christian principles and ideals of God's kingdom envisaged in the Church and the human historical experiences which as the mouthpiece of the coming kingdom of God represents its message to the wider human sociality. Are there any socio-cultural, economic and political implications of reechoing God's active role in making the life of the people become meaningful and peaceful? The study concentrates on the Kingdom of God in its relationship with human history. It focuses on some theological thoughts from both catholic and protestant perspectives. It elucidates the significance of the Kingdom of God in the transformation of human history by first considering the Universal Kingdom of God, as a symbol of hope for humanity and examining critically the socio-political implication of the Kingdom in the proclamation of Jesus the Christ.
\end{abstract}

Keywords: Kingdom of God, Political theology, Historical Experience, Sociopolitical, Social transformation.

(C) 2021 The Author(s). Published and Maintained by Noyam Publishers.

This is an open access article under the CCBY license (http://creativecommons.org/licenses/by/4.0/).

\section{INTRODUCTION}

Human beings owe their existence to God and the reality of life exists in God in his relationship with created beings. ${ }^{1}$ King David emphasized this when he said; "The earth and all therein belongs to God ..." (Ps 24:1-2). Humans, therefore, acknowledge and depend on God who owns them and their existence. "This God leads men to a future which is not mere repetition and confirmation of the present, but is the goal of the events that are now taking place." 2 Jurgen Moltmann like David had said this to drum home the point that, human beings in the constant crossing of cultural frontiers cannot abandon their relationship with the God who makes their existence a real experience. ${ }^{3}$ Using the example of the nation Israel, Moltmann critically emphasizes that, when Israel encountered God and experienced Him in the reality of his promises, Israel's history existed only in so far as God accompanied her. He further makes the point succinctly, emphasizing that "only where Yahweh had revealed himself in his word and acts, was history made possible for Israel by the fact that God was revealed to Israel in his promises and that Israel saw the revealing God again and again in the uttering

Christopher J.H. Wright, Old Testament Ethics for the People of God, (London: IVP, 2009), 181-186.

Jurgen Moltmann, Theology of Hope, (New York: Harper and Row, 1967), 97.

Moltmann, Theology of Hope, 97. 
of his promises." ${ }^{4}$ This can be related to the experience of God in contemporary society. Hence this study seeks to clarify the importance of the kingdom of God in transforming the lives of humankind. It focuses on the theological experience in the Church and society, the kingdom of God and the transformation of human history as a source of hope, and the socio-political implications of the proclamation of Jesus the Christ.

\section{Theological Experience in the Church and Society}

The experience of God in the development of human culture is the encounter with the Word of God based on which humans reflect continually on their relationship with God. "The Word particularly revealed in Christian experience is the reflex of the mission and purpose of Christian theology. Christian theology establishes the hopes and aspirations of the Kingdom of God in the world with the main objective to transform it." 5 Theology or the experience of God as the ultimate reality of human existence and history cannot therefore, be divorced from human experience. In other words, theological claims, whatsoever form it takes cannot deny or violates common human experience. ${ }^{6}$ The history of God and life together with the socio-cultural environment of the people has been known throughout the history of the church and Christian theology. The Christian church has interpreted her biblical positions about the relationship that must exist between the church and society or broadly how God has related or cooperated with the various stages of changing human endeavors. Theologians or church fathers have expressed their opinions on matters of church social issues from the perspectives of traditions and theological positions. For instance and as argued by Samuel W. Kunhiyop, St Thomas Aquinas' theology of the public life has been the foundation of the Roman Catholic position on the relationship between the church and the state. The main thrust of Aquinas' position had "focused on the goodness of God's creation and argued that the state was an expression of the social nature that God had implanted in people at creation." 7

The church and the people defined in the perimeters of the kingdom of God informs the establishment of the kingdom of God but "the state was capable of contributing to the establishment of God's kingdom here on earth, under the guidance of the church." "This stand of Thomas Aquinas on the relationship between the church and the society has positioned Catholic Social thought to develop intentional and cogent theological positions on matters of the state and the wellbeing of the people. It has also given the church the potent force to engage with policymakers and governance systems in the history of the church and state relationships across the globe.

According to Sebastian Kim and Katie Day, St Augustine of Hippo (354-430) ${ }^{9}$ developed a more elaborate position informing the position of the church in matters of social, economic and political exchanges within a state. St. Augustine, according to Jean B. Elshtain, formulated his Christian arguments from the standpoint of his City of God. ${ }^{10}$ The City of God provided the platform from which the church could deal with political, social and economic downturns that were associated with the decline of the Roman Empire. ${ }^{11}$ For R.A. Markus, Augustine's City of God defined the kind of civil society or community within which Christian principles can make positive impacts in enforcing civil liberties, order and stability within the wider society. ${ }^{12}$ The kind of society that Augustine envisaged, as stipulated by Mary T. Clark, was that society or state that gave her sovereignty to a political authority only ordered by God to maintain order. The stability and order of society and the responsibility of members of a particular society were of prime importance to Augustine. He believed that, in ensuring social order, "the role of government was not to inculcate virtue but was limited to preventing disorder, however, both the church and the state, from this perspective share a common objective in securing an earthly peace". ${ }^{13}$ In other words, the state alone cannot maintain social order and peaceful coexistence among the citizenry but would need the partnership of the church in inculcating

\footnotetext{
4 Moltmann, Theology of Hope, 98.

Jurgen Moltmann, God for a Secular Society, (London: SCM Press, 1997), 77.

Moltmann, God for a Secular Society, 78.

Samuel W. Kunhiyop, African Christian Ethics, (Nairobi: Hippo Books, 2008), 93.

Kunhiyop, African Christian Ethics, 93

Sebastian Kim, \& Katie Day (eds.), A Companion to Public Theology (Leiden: Brill, 2017), 41.

10 Jean B. Elshtain, “Augustine”, in P. Scott and W.T. Cavanaugh, (Eds.) The Blackwell Companion to Political Theology (Oxford: Blackwell Publishing, 2004), 35.

11 Kim \& Day (Eds.), A Companion to Public Theology, 41.

12 Robert A. Markus, (Ed.) Augustine: A Collection of Critical Essays (New York: Anchor Books, 1972), xii.

13 Mary T. Clark, Augustine, (London: Continuum, 1994), 101-102.
} 
into the people the right kind of attitudes for peace-building. ${ }^{14}$ All Christians in the view of Augustine who consider themselves as members of the City of God must recognize that they are also members of the earthly city and respect for civic authority is vital to a sustained social order. For Augustine, "membership in the city of God was not meant as an escape from the temporal responsibility or as a devaluation of the temporal world. Christians have a responsibility to contribute to the stability of the earthly peace which is the government's direct concern." 15

The key components of Augustine's thoughts on the relationship that must exist between church and state are summarized as follows: Christian theology must not only be confined to the ecclesial corridors but must be placed in the wider contexts of society, politics and the economy of the state. There must always be "a close connection between the Christian community and wider politics and the implications of the changing socio-political situation surrounding the newly formed religious community." 16 Augustine saw the church as the only institution ordained by God through whom God's sovereignty over society and politics could be demonstrated. This position of the church within the wider civil society provided the church the rationale and responsibility in its public engagements. Augustine observed that, when there is stability and order in society, it allowed the church and secular society to work together for the common good of people within the wider society. ${ }^{17}$ Prominent among Augustine's views is the position that divine rule will always interact with natural law or order so that the state could benefit from the guidance of divine provision or order. According to Kim and Day, Augustine based this argument on the premise that "divine justice would achieve both justice and peace in a sustainable way for both sacred and secular spheres." 18

For Martin Luther, a trained Augustinian monk, the relationship that must exist between the church and the secular state was that God of creation rules over all kingdoms either secular/temporal or spiritual. That is supposed to mean that, the spiritual estate represented by the church could intervene in the temporal but not vice versa. ${ }^{19}$ The basic understanding of Luther's position for Kim and Day was that both the secular state and the church have the same status under God's rule but bore separate and different functions. "While God's spiritual government is under the guidance of the word of God and the Holy Spirit, God's worldly government is effected through the use of sword and civil law by secular rulers as they perform a divine role since God has ordained that order too." ${ }^{20}$ So unlike the two estates, the two kingdoms existed in parallels, and overlap with each other. ${ }^{21}$ Martin Luther confirmed Alister McGrath's thought and observed that political authority must be grounded in divine providence-recognizing God's participatory roles in governance systems. ${ }^{22}$

Similarly, John Calvin had his take on matters bordering on secular society and the church. Calvin modeling his thoughts from a more liberal perspective observed that there must be reconciliation between the church and state. Calvin's observation was founded on the fact that both institutions of church and society were ordained by God to be partners in securing the common interest of the people created by God. ${ }^{23}$ From that standpoint, Calvin concluded that politics was as important to the people as it was to the church. His reason, according to Andrew Bradstock, was that secular government was divinely instituted and rulers have a responsibility to God and to those they govern and citizens should be obedient to any and every form of government. ${ }^{24}$ To the church, Calvin admonished it not to be confrontational when responding to matters of state. The church's engagements of social and political matters must "take the form of supplication, suffering or exile." ${ }^{25}$ Calvin also supported the argument that there are separate and different roles for both the church and the secular state authorities to perform. The state has the coercive powers to engage with citizens whiles the church has the responsibility to promoting virtue in citizens. So in Calvin's views, "magistrates and

\footnotetext{
${ }^{14}$ Kim, \& Day (Eds.), A Companion to Public Theology, 42.

15 Clark, Augustine, 95-103.

16 Kim \& Day (Eds.), A Companion to Public Theology, 43.

${ }^{17}$ Kim \& Day (Eds.), A Companion to Public Theology, 43.

18 Kim \& Day (Eds.), A Companion to Public Theology, 43.

19 Kim \& Day (Eds.), A Companion to Public Theology, 45.

${ }^{20}$ Kim \& Day (Eds.), A Companion to Public Theology, 45.

${ }^{21}$ Kim \& Day (Eds.), A Companion to Public Theology, 45.

22 Alister. McGrath, Reformation Thought: An Introduction, $2^{\text {nd }}$ ed. (Oxford: Blackwell, 1993), 205-2010

${ }^{23}$ Kim \& Day (Eds.), A Companion to Public Theology, 45.

${ }^{24}$ Andrew Bradstock, "The Reformation", in P. Scott and W. T. Cavanaugh, ed., The Blackwell Companion to Political Theology (Oxford: Blackwell Publishing, 2004), 62.

${ }^{25}$ Kim \& Day (Eds.), A Companion to Public Theology, 46.
} 
Christian priests are committed to the same cause and differ only in their spheres of authority."26

Another representative of the Reformation to be considered on matters of church and state relationship is Ulrich Zwingli. For him the state and the church are not to be separated as entities but must have different forms or ways to manage the city, bearing in mind that all must conform to the rule of God. ${ }^{27}$ The Reformation had the objective to first emphasize that, God's providence established both the authorities of the secular state and the church. Secondly, the Reformation understood that both the secular state and the church have one common responsibility towards the common good of citizens but do so from different dimensions and mandates designed by God through which they perform their varied roles. ${ }^{28}$

For the Reformation as well as the Roman Catholic theological tradition, the church has the responsibility to engage with all forms of issues that confront secular society so as to contribute to society's transformation. It is expected that whatever position one holds whether from the general position of the church or from the perspectives of an individual Christian theologian, must be distinctively based on the Christian faith. Such views, for Ronald F. Thiemann, must genuinely address issues of public significance, in order that the distinctive substance of Christianity and its prophetic voice will be manifested. ${ }^{29}$

\section{The Kingdom of God and Transformation of Human History}

Some systematic theologians like Moltmann and Wolfhart Pannenberg and some liberation theologians have all expressed the relative significance in the relationship that must exist between humanity and God's sovereign love. Pannenberg, on his part, shares this view: "the expectation of the kingdom of God explains the factual inseparability of the church and the world. This suggests, that the idea of God's coming kingdom might be the appropriate starting point for a theological understanding of the church." ${ }^{30}$ For him, "the measure by which we evaluate the transformations of political and social forms of life is the measure of love." ${ }^{31}$ The love theme for Pannenberg is the main thrust of the teachings of Jesus and calls it "the final norm of justice [...] love is equipped to the measure of justice because it is not an abstract principle [...] it is a dynamic reality producing in an ongoing process, new forms of human unity." ${ }^{32}$ Jesus himself for Pannenberg was the epitome of love, exemplifying the love of God in his own life and death. "Jesus proved to be the expected Christos, the Messiah of God, who shall establish God's kingdom on earth. The dignity of Jesus as the Christ, as the Messiah is a result of the way he represented and still represents for all humanity the kingdom of God as already determining and transforming the process by creative love." 33 Rebecca S. Chopp had equally suggested that "God always acts in love to transform history into the kingdom of God." 34

The idea of the Kingdom of God as constituted in the history of human existential realities provides illumination to the human journey to the good. This would be realized only in the light of the future of God in relation to humanity's living in human society that recreates itself for a better prospect. ${ }^{35}$ The meaning of God and the understanding of his oversight responsibility in human life is a great teacher for all humanity. This has further been emphasized by Joshua W. Seachris and Stewart Goertz:

The Christian religion teaches that the whole universe and all its inhabitants including ourselves were created and are sustained by God who loves each one of us. The existence of God and his interaction with us makes available to us a deeper understanding of the ultimate nature of things than we would have otherwise. For even if we cannot understand why there is a God, at least we can understand why there are laws of nature and why humans exist because God made and sustains and he seeks to bring about a good state of affairs. ${ }^{36}$

\footnotetext{
${ }^{26}$ Kim \& Day (Eds.), A Companion to Public Theology, 46.

27 McGrath, Reformation Thought: An Introduction, 212.

28 McGrath, Reformation Thought: An Introduction, 212.

29 Ronald F. Thiemann, Constructing a Public Theology: The Church in a Pluralistic Culture (Louisville, KY: John Knox Press, 1991), 24.

30 Wolfhart Pannenberg, Theology and the Kingdom of God, (Philadelphia: The Westminster Press, 1969), 68.

31 Pannenberg, Theology and the Kingdom of God, 80.

32 Pannenberg, Theology and the Kingdom of God, 81.

33 Pannenberg, Theology and the Kingdom of God, 81.

${ }^{34}$ Rebecca S. Chopp, "Latin American liberation Theology", in D.F. Ford (Ed.) The Modern Theologians: Introduction to Christian Theology in the Twentieth Century, (2 ${ }^{\text {nd }}$ ed.), Massachusetts, Blackwell, Publishers, 1997, 418

35 Pannenberg, Theology and the Kingdom of God, 80.

36 J.W. Seachris and S. Goertz, (Eds), God and Meaning, (London: Bloomsbury, 2016), 154.
} 
Jesus's proclamation of the imminent kingdom of God which rather emphasizes an interrelationship between the present and the future rekindles the human spirit of hope in the God of the universe. Pannenberg buttresses the point in the following statement; "God's kingdom does not only lie in the distant future but is imminent. Thus, the present is not independent of the future. Rather does the future have an imperative claiming on the present, alerting all men to the urgency and exclusiveness of seeking first the kingdom of God and his righteousness?" 37 As this message is proclaimed and accepted, God's rule is present and can even now be glimpsed in his future glory. In this way, the present is seen as an effect of the future, in contrast to the conventional assumption that past and present are the causes of the future..$^{38}$

The existence and the command of God on all humanity bring to bear the desire to do more good acts and also aspire to nurture each other to have good character. Moltmann intimates that "the earth is the stage of God [...] For the kingdom of God stands in direct relationship to the earth; it lives now, with the earth [...]. Jesus is the defiance against poverty, sin and misery." ${ }^{39}$ Moltmann reiterates the point that critically puts the human race to the consciousness of the God-factor in the day-to-day life issues they are confronted with, particularly to issues of accountability and responsible stewardship..$^{40}$

\section{The Universal Kingdom of God; Hope for all Humanity}

The dawn of the sovereignty of God in human affairs pertains not uniquely to the people of Israel or Christians. It is an intended mission of God to all humanity in the universe. Christian faith or theology affirms that God establishes a universal hope for the people of the world and the earth through the communities of Israel and the Christian Church (Christianity). Moltmann attesting to this argued: "The future of the church is more than the church; the future of Christianity is more than Christianity. The church answers for God's universal future. Jews and Christians are the people of God's coming kingdom, which was proclaimed through Israel and embodied in person through Jesus Christ." ${ }^{41}$ Making reference to the Vatican II on the Constitution on the Church; Lumen Gentium, ${ }^{42}$ he continued to reiterate the point that, "the church represents the seed and the beginning of God's kingdom on earth." ${ }^{43}$ The major preoccupation of the communities of God whether Jews or Christians is to "work to see the emergence in society and politics, in economic life and culture, of correspondences and anticipations of the kingdom of God and his righteousness which they expect in the world." 44 Pannenberg stressed that "the expectation of the kingdom of God explains the factual inseparability of church and world". ${ }^{45}$ The kingdom of God, it is believed restrains human actions that denigrate the value of the human person created in the image of God.

Van E. Eck throws more light on the issue insisting:

In this exploitative situation caused by the 'kingdom of Rome', and the 'kingdom of temple', the central message of Jesus was the kingdom of God. This kingdom was not a futuristic-apocalyptic reality [...], but was ethical-eschatological in content. It was a kingdom here and now, a transformed world, a kingdom that challenged the kingdoms of this world [...], a kingdom that challenged the exploitative social and economic relations in Jesus' society. This kingdom is the immediate reign of God that is now present in the potential of the human imagination to see the world differently and to act accordingly. ${ }^{46}$

In his view, the relationship that existed between God and Israel represented in his message of the kingdom cannot be viewed in a simplistic form. The 'Kingdom of God' was experienced as constitutive of the formation of Israel as a covenant people. He argued that the study into the history and the development of the covenanted people of Israel was understood to mean the establishment of a nation-state with God as their ruler and the

\footnotetext{
37 Pannenberg, Theology and the Kingdom of God, 54.

38 Pannenberg, Theology and the Kingdom of God, 80.

39 Jurgen Moltmann, Sun of Righteousness, Arise; God's Future for Humanity and the Earth, (Minneapolis: Fortress Press, 2010), 79.

40 Moltmann, Sun of Righteousness, Arise, 79.

41 Moltmann, Sun of Righteousness, Arise, 29.

42 Cf. Lumen Gentium 6 \& 9

43 Moltmann, Sun of Righteousness, Arise, 30.

44 Pannenberg, Theology and the Kingdom of God, 73.

45 Pannenberg, Theology and the Kingdom of God, 73.

46 Van E. Eck, "A Prophet of Old: Jesus the public theologian”, HTS Teologiese Studies/Theological Studies 66(1), no.771 (2009): 10 .
} 
source of their nationhood. ${ }^{47}$ Pannenberg shares his views as thus; "Israel expectation of God's rule developed as the hope of a future in which God's justice would be done without break or limit, both in Israel itself and also among the nations." 48 This meant first that God's own duty would find unrestricted recognition (Zech. $14: 9 ; 16-17$ ). He would thus bring peace to the nations by settling their disputes (Micah 4:1-4).

Moltmann on his part describes the experiences of the people of Israel in their socio-cultural and religious realities in respect of their relationship with God and the implications of the message of the coming kingdom of God. "I will be your God and you shall be my people. But behind this covenant experience with God, there was a still deeper experience of him: I will dwell in the midst of the Israelites. Israel's experience of God is therefore always the experience of the God who indwells Israel, whether it is in the Ark of the Covenant, or in the temple, or in the Torah. ${ }^{49}$ For Moltmann, the Kingdom of God as experienced in the history of Israel was a divine covenant undertaken in a mutual happening. The covenant was intended to bring Israel back to God in obedient service to God and His creation. The kingdom of God was conceived and experienced by Israel as an agenda for building hope into the future of human existence, a life through the consummation of time would experience the completeness of human salvation. Walter. Raushaubush describes the kingdom of God as the hope from the social realities of a people. He affirms,

The Kingdom of God is still a collective conception, involving the whole social life of man. It is not a matter of saving the human atom, but of saving the human organism. It is not a matter of getting individuals to heaven, but of transforming the life on earth into the harmony of heaven. If he put his trust in spiritual forces for the founding of a righteous society, it only proved his sagacity as a societybuilder. If he began his work with the smallest social nuclei, it proved his patience and skill. ${ }^{50}$

Moltmann raises a number of issues relative to the redeeming significance of the proclamation of the kingdom of God as a wake-up call to the people to respond.

First, the kingdom of God is not just a creation and providence phenomenon, but as he put it; “... the ultimately liberating, all-redeeming and therefore eschatological kinship of God over his creation." ${ }_{51}$ It is not intended to meet the "here-and-now expectation of human redemption, but an agenda designed to end the history of human violence, suffering and death and brings about a new creation of all things." 52 The understanding that God dwells within the experience and the history of the people is not ultimately to experience his glory alone but like Isaiah encountered him (6:1ff), the glory of God was only preceding God's prime objective; the message of redemption and the correction of disorder in human history as pertained at the time. The message was intended to reach out to all human history and experience beyond Jewish or Hebrew traditions and boundaries.

Second, Moltmann reiterates that the new message from the proclamation of the kingdom of God has a universal significance. "It embraces heaven and earth. Therefore hope for this kingdom leads us to speak not only of a new earth, but of a new heaven as well. God's presence therefore is to make all things new (Rev. 21:1-5)." ${ }^{53}$ For Moltmann, the agenda is not about establishing a religious kingdom, a private relationship with God, nor a moral authority intended to change human behavior, it is "like God himself, it is universal and without limitation [...] it bursts out the bonds of a divided world. It embraces the religious life as well as the political one, the private as well as social, the living as well as the dead." 54

Third, the immanence of the kingdom of God as Jesus proclaimed, for Moltmann had a dual purpose of raising theological and political questions to the people who encounter the message accompanying the revelation of God and his kingdom. The legitimate question of who rules over the earth is; is it man who was created in the image of God or the creator of the world who rules the world all by himself? The biblical tradition about creation from the beginning reveals as Moltmann identifies, that God created humans in his own image and gave them authority to rule over all creation (Gen. 1:27ff). He reiterates the point that humanity's authority over creation as mandated in the beginning has had a limited allegiance to the creator of

\footnotetext{
47 Van Eck, "A Prophet of Old", 10.

48 Pannenberg, Theology and the Kingdom of God, 73.

49 Moltmann, Sun of Righteousness, Arise, 30.

50 Walter. Raushenbush, Christianity and the Social Crisis in the 21 ${ }^{\text {st }}$ Century, (New York: Harper One, 2007$), 54$.

51 Jurgen Moltmann, The Church in the Power of the Spirit, (Minneapolis: Fortress Press, 1993), 99.

52 Moltmann, The Church in the Power of the Spirit, 100.

53 Moltmann, The Church in the Power of the Spirit, 100.

54 Moltmann, The Church in the Power of the Spirit, 100.
} 
humans and other things, as stated below:

As God's image 'man' is God's earthly representative, deputy and vice-gerent. Corresponding to the creator of all things, he is to rule over creation. Hence the way in which man is expected to rule over the world is neither arbitrary nor unlimited. It takes its dimensions and limitations from the way in which man corresponds to the creator who loves his creation and has pleasure in it. It is only this correspondence which legitimates man's rule over the world. ${ }^{55}$

Humanity is always challenged when it wants to exert its authority over the rest of creation because it is expected that humans must have a re-ignited relationship with God who has continued to maintain his experiences with his creation. ${ }^{56}$ God's kingdom objective is a reminder to all humans that his interest in the things that border on humanity's total life will not be dried up by human weaknesses and limitations. His presence shall always be in the experiences of his revelation and humanity must respond appropriately. Consequently, Jesus the Christ, the revelation and revealer of God the Father, becomes the symbol of hope for the imminent kingdom of God to be established in the history of human existence.

\section{The Kingdom of God in the Proclamations of Jesus the Christ: The Socio-Political Implications}

Jesus' proclamation of the imminence of the kingdom of God is an ethic of response, a response towards the expectation of correcting the social order of human existence. It is an invitation to respond to the redemptive act of God because life was once amidst and the mission of the Messiah was to redeem the already twisted world. Wendell Willis asserts that the ethics of Jesus' proclamation of the kingdom of God is not just a call to repentance or a demand on the people to bring about a perfect society, but a response material to the experience of the goodness of God to all humanity for their peace and tranquil relationships. ${ }^{57}$

The words and deeds of Jesus, (in miracles and in preaching like the message from the Sermon on the Mount) were all intended to establish one fact, which was about the presence of the kingdom of God. "In Jesus' person and ministry, the kingdom of God is present. People can experience the saving activity of God not only as a future hope, but also as a present reality. Therefore the issue of inclusion [...] suggests that the ethical demands of the Sermon on the Mount represent not only the proper response [...] to the kingdom of God as a future hope [...] but also as a present experience [...]. Thus, the ethic of the kingdom is a response ethic, a response to the gracious, salvific activity of God." 58

Jesus boldly presents himself as the present and the future hope of human existence which as Moltmann puts it sets its stamp on life, human actions and suffering in the history of society. Hence mission means not merely propagation of faith and hope, but also the historic transformation of life. The life of the body, including also social and public life, is expected as a sacrifice in day-to-day obedience (Rom. 12.1ff). ${ }^{59}$ This hope and expectation of transformation in the message of the gospel does not stand in opposition to the world but has a polemic and a liberating relationship with the practical realities of the world within which life is lived. The gospel message of Jesus must live to encounter the living realities of human history and culture effectively in order to transform or reform it. Jesus was incarnated into the history and the experience of a people who had lost the hope and the righteousness that gave them the power and the confidence of seeing the next future in joy. However, he had come to declare deliverance from the enemies of the nation. "Whatever aspect any man emphasized, it was still a national and collective idea. It involved the restoration of Israel as a nation to outward independence, security, and, power such as it had under the Davidic kings. It involved that social justice, prosperity, and the happiness for which the Law and the prophets called, and for which the common people always long..." ${ }^{60}$

The relevance of the kingdom of God which man is made to understand in respect of the Jesus' factor is in the fact that, God recreates the human focus on Him, not through the hope that the Jewish experience espoused, but a universal and popular hope under the hands of Jesus the Christ. Raushenbush reiterates the point that, through Jesus, the 'old division of humanity between Jews and Gentiles began to fade out in his

\footnotetext{
55 Moltmann, The Church in the Power of the Spirit, 100.

56 Moltmann, The Church in the Power of the Spirit, 100.

57 Wendell Willis, The Kingdom of God in the 20 $0^{\text {th }}$ century Interpretations, Massachusetts, Hendrickson Pub., $1987,127$.

58 Willis, The Kingdom of God in the $20^{\text {th }}$ century Interpretations, 128.

59 Moltmann, Theology of Hope, 330.

60 Raushenbush ed., Christianity and the Social Crisis in the $21^{\text {st }}$ Century, 4.
} 
mind, and a new dividing line drawn between the good and the evil, between those who opened their heart to the new life and those who closed it. ${ }^{61}$ Don Cuppit, on his part, reaffirmed that Jesus' "Kingdom which is ethical in this world is about committing oneself ethically to life and to one's neighbor here and now, and in the present." ${ }^{62}$ As a result, Jesus, the summit of God's revelation represented the continual and progressive participating of 'theocentric' deliverance consciousness to all peoples of the earth. Jesus must be understood in terms of his role in the socio-historical realities of a people in an ethical-eschatological manner so that life in the current is not postponed into the future, but the transformation is always sought after even in the present realities of the people. The deeds and words of Jesus were demonstrated symbolically in the 'kingdom of God' message ringing in the ears of the people. It has been emphasized by Rauschenbusch:
All the teaching of Jesus and his thinking centered about the hope of the kingdom of God. His moral teachings get their real meaning only when viewed from the center. He was not a Greek philosopher or Hindu pundit teaching the individual the way of emancipation from the world and its passions, but a Hebrew prophet preparing men for the righteous social order. The goodness which he sought to create in men was always the goodness which would enable them to live rightly with their fellow-men and to constitute a true social life. ${ }^{63}$

The participation of God in human history as liberation theologians ${ }^{64}$ perceived it is a work in progress by God through Christ to arouse the hope of the people for the 'creation of all things new' and making them anticipate hope for a peaceful future as expressed by Moltmann: "We hear the cry of those who long for peace. The hungry and the exploited cry out for justice. [...]. Millions are seeking meaning in their lives [...] trusting in God's renewing power, we call upon you to participate in the anticipation of God's kingdom and to allow now something of the new creation to become already visible which Christ will complete on his day" ${ }^{65}$ For him, the practical realities of Jesus transforming human socio-historical realities must be realized in ensuring that there are "efforts at making peace and cooperation work among peoples of the world; efforts for social justice in the gulf between the rich and the poor in various societies and between nations and also efforts for an orientation toward the shared life of human beings and all living things in the living space of the earth." The precarious situation of the deprived, the destitute simply the have-nots, or the socio-economically challenged during the time of Jesus was to live on the verge of destitution and poverty always at the mercy of the elite. Martin Goodman describes it in the following words; "The only way to survive was to borrow from the elite and the elite were always willing to invest in these loans (with interest rates up to 48\%); they knew that their debtors would not be able to pay their debts, which in turn gave them the opportunity to foreclose and add the peasants' land to their own estates." ${ }^{67} \mathrm{John} \mathrm{S.} \mathrm{Kloppenborg} \mathrm{describes} \mathrm{it} \mathrm{in} \mathrm{the} \mathrm{following} \mathrm{terms:}$ "the peasantry was constantly threatened with downward mobility and a loss of subsistence, being displaced from small-holder to tenant, then from tenant to dependent day laborer and eventually ending up as part of the expendables of society." 68

Hence Jesus' approach was to provide an alternate socio-political rule that recommended hope for the people. The central message of Jesus according to Van Eck was the 'kingdom of God', which was for the earth, political, religious and involved a transformed world. ${ }^{69}$ The elite kingdoms used social and religious institutions to exploit the people, but the kingdom of God declarations of Jesus constituted an alternate solution to the exploitation of the people by established human institutions..$^{70}$ Jesus exhibited his social appeal to the people when he provided "an alternative to the exploitative systems of the ruling class and also of the temple authorities. A leadership that emphasized a positive image for human dignity and that stand in conflict and

\footnotetext{
${ }^{61}$ Raushenbush, Christianity and the Social Crisis in the $21^{\text {st }}$ Century, 51.

62 Don Cuppit "Reforming Christianity" in K. Armstrong, D. Cuppit, R. W. Funk, L. Geering, J. S. Spong and Fellows of the Jesus Seminar, The once and future faith, (2011), Polebridge Press, Santa Rosa, CA. 55.

${ }^{63}$ Rauschenbusch, Christianity and the Social Crisis in the $21^{\text {st }}$ Century, 55.

${ }^{64}$ Gustavo Gutierrez, We drink from our own Wells. The Spiritual Journey of a People, (New York, Orbis Books), 1995. $122-126$

${ }^{65}$ Moltmann, Ethics of Hope, 36.

${ }^{66}$ Moltmann, Ethics of Hope, 36.

${ }^{67}$ Martin Goodman, The Ruling Class of Judaea (Cambridge: Cambridge University Press, 1987), 29.

68 John .S. Kloppenborg, Tenants in the vineyard: Ideology, economics, and agrarian conflict in Jewish Palestine (Tubingen: Mohr Siebeck: WUNT, 2006), 195.

69 Van Eck, "A prophet of Old: Jesus the Public Theologian”, 5.

70 Van Eck, "A prophet of Old: Jesus the Public Theologian”, 5.
} 
threat to the Roman system of leadership and the system of authority that the religious systems exhibited." 71

It is important to speak against all intentions and actions carried out against human beings because they become part of the history of the people and God's history. "The horror doesn't wear off with time. The remembrance does not fade. For before God there is no statute of limitations, either through the detachment of the past or through the alleged grace of a late birth." ${ }^{\prime 2}$ The declaration of the kingdom of God by Jesus was mostly done in parables. Parables were presented in natural language so that real-life situations could effectively be related and relived. The parables of Jesus emphasized an alternative institution guided by a culturally ruled value system that ensured the right of all people in society to a meaningful life, and that was the kingdom of God. Jesus connected human life with nature which gave the assurance that, they present the beginnings of life processes of hope. ${ }^{73}$ The parable of the mustard seed as Mark's Gospel (Chapter 4) demonstrates, for example, the story of life-process from a small beginning, originating from God, then the effects will be great and marvelous. There are other areas that Jesus appealed to the people he interacted with, which Van Eck describes as the 'social illnesses' of Jesus' day. They are; 'religious exclusivism', which was promoted by the Jewish religious fundamentals in their understanding of how God relates in his holiness to the world. The second element that Jesus stood in contradistinction to the systems at the time is social injustice, exhibited by the Roman elites and the Jewish religious elites. Those elements were considered by Jesus as social ills because they had exploitative tendencies on the life of ordinary people and even on the life of the perpetrators of those dehumanizing practices. Van Eck suggests that, contrary to the Jewish temple elite's politics of holiness, Jesus advocated a politics of compassion, where the socially impure like the blind, lame, cripples, lepers and women are invited and included in the kingdom of God. The parables of the mustard seed and the great banquet all speak to the issues of inclusivity and 'politics of compassion' as Jesus presented to the ordinary people of the times. To Jesus, the kingdom of God seeks to welcome all people to encounter the compassionate heart of God to seek his righteousness and then respond accordingly to the will of God.

\section{CONCLUSION}

The values of the kingdom of God as Jesus declared were meant for radical change in society; welcoming social outcasts, and abandoning violence. Jesus had only one duty to bring to bear on humanity, the coming kingdom of God which is destined for the transformation of the whole of human life. He decried the form of social and religious injustices that ordinary people in first-century Palestine were subjected to. Jesus did not envisage a utopian society in which all was expected to be perfect but only reflected on the socio-religious and politico-economic milieu of the time, engaged in a social analysis that only laid bare the social challenges that confronted the people which needed a transformation. He therefore, painted a picture of a kingdom whose ruler exudes compassionate and inclusive characteristics, a kingdom in which there is no place for exploitation and systemic injustice.

\section{ABOUT AUTHORS}

Very Rev. Fr. Dr. Francis Appiah-Kubi, Senior Lecturer at the Kwame Nkrumah University of Science and Technology, Kumasi, Ghana and a former Head of the Department of the Religious Studies Department at the Faculty of Social Science in the KNUST. He is currently Chairman of Tender Evaluation Panel (Goods and Services - Procurement). He holds PhD degree from both Institut Catholique (2005) de Paris and Catholic University, Leuven and Master's degree in Theology from Facultes Catholiques de Congo (1995). He thought in St. Peter's Major Seminary from 2005-2011. He is immediate past President of the National Union of Ghana Catholic Diocesan Priests' Associations (NUGDPA) and at the same time a Parish Priest of St. Anthony Catholic Church, Kwamo. He is also a visiting lecturer to the St. Gregory the Great Major seminary KumasiGhana and Ecumenical Institute Al Mowafaqa, Rabat Morocco. He equally works with other theological institutes such as San Francisco Theological Seminary in the USA and the Spiritan University College in Ghana. He is a Ghanaian Theologian specialized in Ecclesiology and studies in African Traditional Religions. $\mathrm{He}$ is a member of Comitheol at the service of Symposium of Episcopal Conference of African and Madagascar. Among his publications is the L'Eglise Famille de Dieu; Un chemin pour les Eglise d'Afrique, Karthala, 2008.

\footnotetext{
71 Van Eck, "A prophet of Old: Jesus the Public Theologian", 5.

72 Moltmann, God for a Secular Society, 170.

${ }^{73}$ Moltmann, Jurgen. Jesus Christ for Today's World, (Minneapolis: Fortress Press, 1994), 10.
} 
Rev. Dr. Isaac Osei Karkari, an ordained Minister of the Methodist Church Ghana obtained his PhD degree in Religious Studies at the Kwame Nkrumah University of Science and Technology in 2019. His doctoral thesis was on "Towards the Praxis of Public Theology for the Contemporary African Church and Society: The case of Ghana." He had his Bachelor of Divinity degree and Master of Theology in 2007 and 2013 respectively from the Trinity Theological Seminary, Legon, Accra. His special research area includes ecclesiology and ethical issues facing Christian theology in African context. He is a member of the faculty of the theological education of the Methodist Church Ghana for the training of ministers; He is also a part-time lecturer in Philosophy and Christian Ethics at the Trinity Theological Seminary, Legon Accra.

\section{BIBLIOGRAPHY}

Bradstock, A., "The Reformation", in P. Scott and W. T. Cavanaugh, ed., The Blackwell Companion to Political Theology (Oxford: Blackwell Publishing, 2004).

Chopp, R.S., "Latin American liberation Theology", in D.F. Ford (Ed.) The Modern Theologians: Introduction to Christian Theology in the Twentieth Century, (2 ${ }^{\text {nd }}$ ed.), Massachusetts, Blackwell, Publishers, 1997.

Clark, M.T., Augustine, (London: Continuum, 1994).

Cuppit, D., "Reforming Christianity" in K. Armstrong, D. Cuppit, et al., and Fellows of the Jesus Seminar, The once and future faith, Cincinnati, Santa Rosa Polebridge Press, (2011).

Elshtain, J.B., "Augustine", in P. Scott and W.T. Cavanaugh, (Eds.) The Blackwell Companion to Political Theology (Oxford: Blackwell Publishing, 2004).

Goodman, M. The Ruling Class of Judaea (Cambridge: Cambridge University Press, 1987).

Gutierrez, G. We drink from our own Wells. The Spiritual Journey of a People, (New York, Orbis Books) 1995

Kim, S. \& Day, K., (Eds.), A Companion to Public Theology (Leiden: Brill, 2017).

Kloppenborg, J.S. Tenants in the vineyard: Ideology, economics, and agrarian conflict in Jewish Palestine (Tubingen: Mohr Siebeck: WUNT, 2006).

Kunhiyop, S.W., African Christian Ethics, (Nairobi: Hippo Books, 2008).

McGrath, A., Reformation Thought: An Introduction, $2^{\text {nd }}$ ed. (Oxford: Blackwell, 1993), 205-2010

Markus, R.A., (Ed.) Augustine: A Collection of Critical Essays (New York: Anchor Books, 1972). . Jesus Christ for Today's World, (Minneapolis: Fortress Press, 1994). The Church in the Power of the Spirit, (Minneapolis: Fortress Press, 1993). Sun of Righteousness, Arise; God's Future for Humanity and the Earth, (Minneapolis: Fortress Press, 2010). Theology of Hope, (New York: Harper and Row, 1967). . God for a Secular Society, (London: SCM Press, 1997). . Ethics of Hope, (Minneapolis: Fortress Press, 2012).

Pannenberg, W., Systematic Theology (Grand Rapids, Michigan: W. B. Eerdmans Publishing Company, 1998). . Theology and the Kingdom of God, (Philadelphia: The Westminster Press, 1969).

Raushenbush,Walter, Christianity and the Social Crisis in the $21^{\text {st }}$ Century, (New York: Harper One, 2007). Seachris J.W. and Goertz, S., (Eds.), God and Meaning, (London: Bloomsbury, 2016).

Thiemann, R.F., Constructing a Public Theology: The Church in a Pluralistic Culture (Louisville, KY: John Knox Press, 1991).

Van Eck, E., "The Prophet of Old: Jesus, the public Theologian", HTS Theological Studies 66 (1) 1-10

Willis, W. The Kingdom of God in the $20^{\text {th }}$ century Interpretations, Massachusetts, Hendrickson Pub., 1987, 127.

Wright, J.H.C., Old Testament Ethics for the People of God (London: IVP, 2009). 